\title{
Characters' Attitude Towards the Environment in Bunga Rampai Ceritera Rakyat Daerah Kalimantan Barat by Darwis Saramat
}

\author{
Marwah Ulwatunnisa* \\ Graduate School \\ Universitas Negeri Yogyakarta \\ Yogyakarta, Indonesia \\ marwahulwatunnisa.2018@student.uny.ac.id
}

\author{
Wiyatmi \\ Graduate School \\ Universitas Negeri Yogyakarta \\ Yogyakarta, Indonesia \\ wiyatmi@uny.ac.id
}

\begin{abstract}
This study aims to describe the attitudes of the characters towards the environment in Indonesian folklore, which is a folk story, entitled Bunga Rampai Ceritera Rakyat of West Kalimantan Region retold by Darwis Saramat. This research used an ecocriticism study. The data source used was the book entitled Bunga Rampai Ceritera Rakyat of West Kalimantan. The research method used was descriptive qualitative. The results of this study were; the characters in folklore have moral principled attitudes based on environmental ethics; respect for nature, the principle of responsibility and the principle of living simply and in harmony with nature. Indigenous people have a life that is in harmony with nature and unconsciously believes in supernatural beings and farming customs play a role in protecting the natural environment. The dominant form of ecological criticism is that it should not to be careless in utilizing nature.
\end{abstract}

Keywords - attitude, ecocriticism, environment

\section{INTRODUCTION}

The book entitled Bunga Rampai Ceritera Rakyat of West Kalimantan Region contains three folktales from West Kalimantan written by Darwis Saramat. The stories entitled Tan Unggal, The Origin of the Name Sintang, and The Origin of Kendayan Tribe. This book was published in 1982 and had stories that were closely related to the natural environment. Especially the story entitled The Origin of the Name Sintang, which describes the concept of farming. Folk stories as part of folklore mean that part of a collective culture, which is passed down through generations traditionally in many versions, the form can be verbal accompanied by gestures or reminders (Danandjaja, 1994: 1-2). There are several figures found in this story including seven siblings named, Puyung Gana, Pinggang Belang, Suluh Duik, Buku Labuk, Terentang Temanai, Putung Kempat (women), and Bui Nasi. Puyung Gana died since he was a child, but he is considered alive as a ghost. Puyung Gana is then referred to as the owner of the whole land. Anyone who will use the land, cut down trees, or farming, should first getting permission from him. Some conditions must also be fulfilled.

This story is about the belief of the land-owner, Puyung Gana and the traditions carried out during farming. According to Siahaan (2004: 44), the nature of the natural balance still can be maintained thanks to the community that still adheres to a view based on the rules of life, traditions or customs that are mythical, and mystical. In the past, the impact of land clearing for farming was only local. In the opinion of Kemp (2004: 6), environmental impacts are local and short-term. Loss of vegetation and reduction in the animal population are also temporary.

This condition is different from now. The utilization of nature by humans becomes arbitrary. For example, the burning of forests to clear land on a large scale that occurred in several regions in Indonesia. In 2014 it reached 44,411.36 ha, in 2015 it reached the highest number of 2,611,411.44 ha, in 2016 an area of 438,363.19 ha, in 2017 , it reached $165,483.92,510,564.21$ ha and in 2019 reached 328,722 ha (sipongi.menlhk.go.id). This has a long-term impact on the habitat and population of flora and fauna. Even air pollution spread to several regions. Yet according to Siahaan (2004: 43), the human is subsystems of the environmental ecosystem.

Therefore, many studies link literature and environmental works. According to Love (2003: 16), teaching and studying literature without reference to the natural conditions of the world and the basic ecological principles that underlie all life will be odd. Literature work is a work of fiction, not just imagination. Nurgiyantoro (2013: 3) suggests that fiction tells the various problems of human life in their interactions with the environment and others, their interactions with oneself and their interactions with God. Even according to Nurgiyantoro, fiction offers "models" of life as idealized by the author as well as showing his figure as an aesthetic artwork. The function of folklore as a work of fiction according to Teeuw $(2003 ; 60)$; it can be a docere, which means to teach something to the reader, delectare means to give pleasure, entertainment, a benefit to the reader, and the movere which means to move the reader to something positive.

Based on the above writing, Maimunah (2014) through an ecocritical perspective trying to find solutions to ecological problems by utilizing literature works as a media to build awareness of environmental issues. For example, Wiyatmi (2016) who related his research on the novel Amba by Laksmi Pamuntjak, which not only depicts the history of 30 September 1965 but also illustrates ecological issues. Critics of the exploration and exploitation of natural resources on Buru Island. Wiyatmi (2015: 49) argues that a study of literary works using ecocriticism will explain nature, the environment, with 
various problems being an inseparable part of literary works.

Ecocritics is a term that was coined in the late 1970s by combining "criticism" and "ecology" (Abrams, 2009: 87). This means the science that investigates the relationship of all forms of plant and animal life with each other and with their physical habitat. Kemp (2004: 1) believes ecology cares about the biotic (living) and abiotic (nonliving) elements on earth and their interactions with one another. Glotfelty (1996: xviii-xix) in his book The Ecocritics reader Landmark in Literary Ecology argues that an ecocritic is a study of the relationship between literary works and the physical environment. Ecological criticism, according to Glotfelty, has the basic rationale of human culture that is connected to the physical world, both of which influencing and influenced one another. Ecocritics also expand the idea of "the world" to include the entire ecosphere or ecosystem of the planet, which involves all creatures and all their environmental components.

Thus, ecocriticism refers to critical writing that explores the relationship between literature and the biological and physical environment, which is carried out with acute awareness of the damage done to the environment by human activities (Abrams, 2009: 87). Ecocritics seek to express critical opinions about the human mistreatment of nature and the environment, which is getting worse (Wang, 2014). Ecocritics develop as explicit critical responses to dialogues that have never been heard and as an effort to raise the level of human awareness (Love, 2003: 16).

Through an ecocritical perspective, researchers try to examine the attitudes of characters towards the natural environment. Attitudes according to Hall (1993: 28) related to the orientation of people in certain aspects of the environment (including towards others, culture, and society). Attitudes towards the environment can be seen through the moral principles described in Keraf's book titled environmental ethics. The nine moral principles were written by Keraf (2010: 167-176). It can be used as a handbook or guide for human behavior in treating the natural environment. The nine principles are as follows. The first principle is respect for nature, the second is responsible for nature, the third is cosmic solidarity, the fourth is compassion and concern for nature, the fifth is the principle no-harm, the sixth is living simply and in harmony with nature, which the seventh is justice, the eighth is democracy, and the ninth is moral integrity.

Three principles become a reference in this research. First, the attitudes of respecting nature, that humans as a moral agent, have a moral obligation to respect life, both in humans and other creatures in the ecological community as a whole. Second, the principle of responsibility, that is human as part of the universe, has the responsibility to maintain and preserving nature. This responsibility is not only individual but also collective. Third, the principle of simple living and in harmony with nature. Human does not need to be greedy, do not need to hoard a lot and exploiting nature without knowing the limits. This means that the pattern of consumption and production of modern humans should be limited. There must be a limit that can be tolerated by nature. Juliasih (2015) in her article, stated that actions based on moral principles need to be considered in social, political and economic policies. Also, people must actively apply environmental ethics.

Furthermore, through an ecocriticism study of folklore from the book Bunga Rampai Ceritera Rakyat of West Kalimantan Region, it can be expressed an understanding of the importance of harmonious relations between humans, the environment and other God's creatures. The characters in the folklore are said to be of the Dayak tribes. They can be said to be the Dayak indigenous people in West Kalimantan. Dayak tribes in West Kalimantan are diverse. There are Dayak Iban, Dayak Kayan, Dayak Taman, and others. Indigenous Dayak people are all people who are genealogically born as Dayaks who recognize, respect, implement, fight for and live in a specific life order and cultural order that is passed down and carried on from one generation to another generation of Dayak tribes (Sandi, 2019: 28-29).

The characters in this folklore are very close to the myth. In this folklore, parents of seven siblings deliberately put themselves in the granary (kepok) for seven days to turn into seeds or plant seeds. The sacrifice is made for the lives of their children in the future. Consider the following quote.

...When granary is finished, we as your parents will enter it. Then you close tightly. After seven days, then opened. Surely you will see a variety of seeds. And don't forget that the seeds must all be planted and will be useful for your descendants in the days to come.... (Saramat, 1982: 14).

Also, the figures as a Dayak community entrust the environment, such as the Puyung Gana figures who are said to be supernatural beings and guardians of the land). According to Siahaan (2004: 43- 44), the efforts to sanctified the environment are done so that nature is not treated arbitrarily. Then the forests are not cut down carelessly, river fish are not taken in excessive ways. Cliff lands are not dredged by damaging. The characters in this folklore indirectly describe the role of the Dayak indigenous people in protecting the natural environment.

The research problems are as follows. First, the attitude is shown by the characters towards the environment. This can be known through moral principles in environmental ethics. Secondly, through an ecocritical perspective, it can be seen the role of indigenous peoples in protecting the natural environment.

\section{METHODOLOGY}

The study was a qualitative descriptive study. Qualitative research according to Moleong (2006: 6) is a research that has the intention to understand the phenomena about what is experienced by research subjects such as behavior, perception, motivation, actions holistically, with a special natural context and by utilizing various scientific methods. The primary data source is the 
book Bunga Rampai Ceritera Rakyat of West Kalimantan Region in 1982. Secondary data are in the form of books related to ecocriticism and environmental science, as well as other books and research that support this research.

Data analysis is done by reading the book Bunga Rampai Ceritera Rakyat of West Kalimantan. This book is downloaded via repository.kemendikbud.go.id site. Data collected and categorized as follows. First, the attitudes shown by the characters as local people towards the environment. This can be known through the moral principles of environmental ethics by Keraf. Second, the role of indigenous peoples in preserving nature.

\section{RESEARCH RESULTS AND DISCUSSION}

The characters in this folklore book are seven siblings named Puyung Gana, Pinggang Belang, Suluh Duik, Buku Labuk, Terentang Temanai, Putung Kempat (women), and Bui Nasi. The results showed the character's attitude towards nature; respect for nature, responsibility for nature, and the principle of living simply and in harmony with nature. Finally, the characters who are indigenous Dayak people have a role in protecting the natural environment. Future explanations are on the following discussion.

\section{A. Respect for nature}

Based on the folklore analyzed, the attitude of respecting nature is reflected in the characters of Pinggang Belang, Suluh Duik, Labuk, Terentang Temanai, Putung Kempat (women), and Bui Nasi against Puyung Gana as the landowners. Puyung Gana conveys some conditions in farming by paying attention to three constellations of stars. Then six of his siblings accepted and respected the conditions.

Meanwhile, he also asked: "How can you work out the fields easily?" Then Puyung Gana as the oldest sibling explained as follows. He said: "We must pay attention to the three constellations." The three constellations are as follows: Three-star - a sign of begins working on the field. Five-star - a sign of the season of cutting wood. Four-star - a sign of rice being hit by a disaster. Maybe a pig, maybe a pest. Until now, people of Sintang still believe in these natural signs (Saramat, 1982: 18).

Based on the quote above, the meaning of the three stars is to start working in the fields. Five-star means the season for cutting wood. Four-star means the rice will be affected by disasters, such as pests or pigs. The conditions conveyed by Puyung Gana contain certain stages in opening a field. This must be done as a form of respect for Puyung Gana and his brothers would not open the fields as they pleased. Consider the following quotes.

Seeing the first star, that does not mean continuing to open the fields immediately. However, before opening a field, a traditional ceremony must be held first. Hold a victim and ask permission from the subtle spirit. The subtle spirit is Puyung Gana himself. Materials for victims have also been outlined by Puyung Gana himself (Saramat, 1982: 18).

In the first condition, in opening a field, they should hold a ceremony first. They have to get permission from Puyung Gana while serving some portion, which consists of some things. After the harvest, they also have to thank God.

... After the harvest, do not forget to have giving thanks. Thanksgiving party. Until now, these tribes have always held great thanksgiving parties. Sometimes to spend all the harvest. This customary party in the local language is called "The Traditional Party of Ngumpat Batu Nyapat Tahun" (Saramat, 1982: 19).

Based on the data above, there is an attitude of admiration and respect from the six siblings namely Belang Pinggang, Suluh Duik, Buku Labuk, Terentang Temanai, Putung Kempat (woman), and Bui Nasi towards Puyung Gana as the landowner. The Puyung Gana brothers are willing to fulfill the conditions submitted so that their harvest is successful. The things they do have a positive impact on the natural environment. This means that not arbitrarily cut down forests for farming. They also must thank God as the creator of the universe, if their harvest is successful.

\section{$B$. The principle of responsibility}

The principle of responsibility arises from the figure of Puyung Gana. He is a ghost or supernatural being who owns the whole land. Therefore, he feels responsible for land management. Puyung Gana has the power to return the trees that have been cut down to become normal again.

... And they went into the forest to cut wood to make fields. There was very much joy in their hearts at the work of cutting down that forest. A clear and bright wood forest appears ... (Saramat, 1982: 15).

Suddenly a voice that was even more frightening. "Kas stranded, continued all raras"! Following this voice, it was clear that the points of wood that had been cut down by them began to stand up and united again as usual. These words are repeated until early morning (Saramat, 1982: 17).

The quote above depicts a wilderness that has become spacious and bright land. This means that no longer visible lush tree. Then, it was described the unseen event when the trees which were cut down by six Puyung Gana brothers returned intact. This was done by Puyung Gana with his supernatural powers. He just said, "Kas stranded, continued all raras"!. The reason why Puyung Gana did it was that he did not want his land to be used without 
permission. Puyung Gana's origin as a landowner is illustrated by the following quote.

Puyung Gana warned, the act of throwing a lump of earth in the past. Throwing a lump of land for him has been used as an excuse to control the entire land. Therefore, anyone who will open a field should ask for permission from Puyung Gana (Saramat, 1982: $18)$.

In the past, Gana's younger brother once threw a lump at the Puyung Gana. Therefore, Puyung Gana felt like he is controlling of the whole land. Whoever wants to open a field should first get permission from him. Thus, Puyung Gana indirectly has the responsibility for managing the land.

\section{The principle of life is simple and in harmony with nature}

At present, the population of human life and high consumption is the most influential thing in the natural environment. Human population and consumption are pressing for contemporary environmental problems (Kemmemer, 2019). This folklore portrays people used to live using nature according to their needs. Therefore, based on this principle, when humans understand themselves as an integral part of nature, they must use nature as needed. The equipment used is also still traditional. Maryadi (1991: 7-8) argues that Indonesian people have always been familiar with the cultivation system in the field, based on hereditary inheritance, as well as the production and distribution equipment. In the past, the concept or system of farming was still traditional. Populations and needs are also still low.

... And without saying much, they swung their axes sharply to cut down the sticks. The sound of axes and the roar of fallen woods added to the crowd in the forest. And the wood has all fallen ... (Saramat 1982: 16).

With all the tools made of stone, such as axes and others, they began to cut down the wood. Nevertheless, this effort was unsuccessful. Then the stone ax was tied with a rattan rope to a piece of wood as the handle. Then they cut the wood again. When it was almost finished cutting the wood, the night had arrived and prevented them from completing the work ... (Saramat, 1982: 35).

Based on the above quotation, the six brothers traditionally make the fields. They worked together, cutting down trees in the forest. The tool they use is still traditional, namely the ax. This indicates there is no technology or other modern tools used to cut down trees. They live as humans who try to adjust and coexist with nature. They only use the land as needed for farming. Based on this situation, it can be seen that the character's attitude is still based on simple principles and in harmony with nature.

\section{The role of indigenous peoples in protecting the natural environment}

The story is titled "The Origin of the Name Sintang" in Bunga Rampai Cerita Rakyat of West Kalimantan Region has a background in the Sintang region. Sintang is derived from the word "senentang" because around the area there are many tributaries that flow in opposition to one another. Sintang comes from the term or language of the Dayak tribe who inhabit the inland Kapuas river area in West Kalimantan.

...According to the belief of the Daya, the Jubata Air bursts always lead to a disease of mulang or leprosy...(1982: 14).

It can be seen from the quote above that the characters in the story. Puyung Gana and his six brothers can be said to be the Dayak indigenous people of West Kalimantan. Kalimantan has various Dayak tribes, such as the Dayak Iban, Dayak Kayan, Dayak Taman, and others. Then based on the contents of folklore, some customs are closely related to the environment. Based on the folklore, two customs were discovered, Persembahan Pangkal Benih and Pesta Adat Ngumpat Batu Nyapat Tahun. The name of this custom might be a bit different from what is in society today. Consider the following quotes.

All of these requirements must be lined up, organized neatly, these victims are called "persembahan pangkal benih". To lay the base of the seed, it is very important to hear the sound of birds. If you have heard the sound of a bird, it is a good sign, and later after three days I, Puyung Gana will appear. If you see me fully clothed, as usual, it means you have to give a "hitcher" (dish). Ask permission and have to give food to Puyung Gana. This is a sign that you will get a satisfying harvest (Saramat, 1982: 19).

The above quote explains a tradition called "persembahan pangkal benih". Before laying seeds in the ground, the community must prepare a variety of offerings according to what Puyung Gana said. The community must also pay attention to the sound of birds. This is following the case study by Dove (1988), which was the preliminary selection of places and ignoring of bird signs. Bird sounds in this story indicate that Puyung Gana will appear. It was then that the community gave the "scavenger" or dish. This indicates that they will get a satisfying harvest. Thus, indigenous people truly believe in the signs of nature and respect nature as a source of meeting needs. They treat nature as part of them, so it is not treated haphazardly. The natural environment is not just an object to be used and exploited.

... After the harvest, don't forget to have to give thanks. Thanksgiving party. Until now, 
these tribes have always held great thanksgiving parties. Sometimes to spend all the harvest. This customary party in the local language is called "The Traditional Party of Ngumpat Batu Nyapat Tahun" (Saramat, 1982: 19).

The second custom is "Ngumpat Batu Nyapat Tahun traditional party", this is a thanksgiving party after harvest. This is done as a form of honoring God who gives the harvest. This thanksgiving party can be a reminder for the human to always be grateful for the natural wealth and results provided through this earth. Besides, it was said that there was a custom of "bathing simburan" in this thanksgiving party. Consider the following quote.

Then a party of seven days and seven nights was held. While they were in this atmosphere of extraordinary excitement, they bathed in the river. And shower with the children's water. "bathing simburan" custom is a custom that still applies to this tribe. However, because they forgot to flush Putung Kempat with water, finally Putung Kempat was affected by leprosy (Saramat, 1982: 16).

It is said that this thanksgiving party was held for seven days and seven nights by the six siblings. They also carry out "bathing simburan". When someone does not meet these requirements may be affected by a disease or difficulty. In the past, myths became close to society, there were beliefs related to cause and effect.

Based on the above explanation, folklore as a literary work can provide an ecological critique. Callaghan writes based on the view of Burke Kennet, the important thing through literature is simply to realize how we become part of nature, rather than being different from the physical universe and fostering humility to care and imagine ourselves in a larger ecology (Callaghan, 2015).

\section{CONCLUSION}

Based on the results of research and discussion, several conclusions are as follows. First, figures in folklore have moral principles based on environmental ethics, which are; respect for nature, the principle of responsibility and the principle of living simply and in harmony with nature. Second, the characters in the story as indigenous peoples carry out customs that represent a form of respect for nature, respect for the guardian of the land (Puyung Gana) and remembering God. Indigenous peoples indirectly have a role in protecting the natural environment. A form of ecological criticism that is not to use nature carelessly.

\section{ACKNOWLEDGMENTS}

Thanks to Allah SWT so that the writer has the opportunity to finish this article. Thanks to Dr. Kastam Syamsi M.Ed as chairperson of the Indonesian Language and Literature of Postgraduate Program at Yogyakarta
State University. Thanks to Dr. Wiyatmi M.Hum and the ICLLAE Editorial Team.

\section{REFERENCES}

Abrams, M. H., \& Geoffrey G.H. (2009). A glossary of literary terms ( ${ }^{\text {th }}$ ed.). Boston: Wadsworth Cengage Learning.

Callaghan P. (2015). Myth as a site of ecocritical inquiry: disrupting anthropocentrism. ISLE. 22(1): 80-97, doi: https://doi.org/10.1093/isle/isu127.

Danandjaja, J. (1994). Folklor Indonesia: ilmu gosip, dongeng, dan lain lain. Jakarta: PT Temprint.

Dove, M. R. 1988. Sistem perladangan di Indonesia:suatu studi kasus dari Kalimantan Barat. UGM press : Yogyakarta.

Glotfelty, C., \& Harold F. (1996). The ecocriticsm reader landmark in literary ecology. Georgia: Universitas of Georgea Press.

Hall, C.S., \& Lindzey G. (1993). Psikologi kepribadian 3 teori-teori sifat dan behavioristik. Yogyakarta: Kanisius.

Juliasih k. (2015). Manusia dan lingkungan dalam novel life in the iron mills karya rebecca hardings davis. Jurnal Litera. Universitas Negei Yogyakarta. 11(1).

Kemp, David D. (2004). Exploring environmental issues; an integrated approach. London and Newyork: Routledge.

Keraf, A.S. (2010). Etika lingkungan hidup. Jakarta: Penerbit Buku Kompas.

Kemmemer L. 2.019. The interconnected nature of anymal and earth activism. American Behavioral Scientist. 63(8) 1061-1079. doi: $10.1177 / 0002764219830460$

Love G.A. (2003). Practical ecocriticism; literature, biology, and the Environment. USA : University of Virginia Press.

Maimunah. (2014). Perlawanan alam terhadap kolonialisme dalam novel pohon jejawi karya Budi Darma. Jurnal Litera: Universitas Negeri Yogyakarta.13(2)

Maryadi, Rohany, M. Ikot Rinding, \& Dahyar Deswandra. (1991). Peralatan produksi tradisional dan perkembangannya daerah Kalimantan Barat. Departemen Pendidikan dan Kebudayaan kalimantan Barat.

Moleong, L.J. (2006). Metodologi penelitian kualitatif (Rev. Ed.). Bandung: PT Remaja Rosdakarya.

Nurgiyantoro B. (2013). Teori pengkajian fiksi. Yogyakarta: UGM Press

Sandi J.R.A. 2019. Lembaga adat dan hak-hak adat masyarakat Dayak dalam pusaran politik. Studi kasus kalimantan tengah 2011 2016. An1mage: Banten.

Saramat D. (1982). Bunga rampai ceritera rakyat daerah Kalimantan Barat. Departemen Pendidikan dan Kebudayaan.

Siahaan, N.H.T. (2004). Hukum lingkungan dan ekologi pembangunan. Yogyakarta: Erlangga.

Teeuw A. (2003). Sastera dan ilmu sastera. Jakarta: Pustaka Jaya.

Wang N. (2014). Global in the local: ecocriticism in china. ISLE: Interdisciplinary Studies in Literature and Environment. 21(4):739-748, doi: https://doi.org/10.1093/isle/isu153. Epub 19 Jan 2015.

Wiyatmi. (2015). Kritik sastra indonesia; feminisme, ekokritisisme, dan new historisme. Yogyakarta: Interlude Yogyakarta. 
Wiyatmi. 2016. Conquest and care for the preservation of nature and environment in the novel amba by laksmi pamuntjak:study ecocriticism. Humaniora. Universitas Negeri Yogyakarta. 